\title{
PERENCANAAN KEBUTUHAN BAHAN BAKU PRODUK SONGKOK DENGAN MENGGUNAKAN METODE MATERIAL REQUIREMENT PLANNING \\ (Studi Kasus: UMKM Putroe Sarjana Songkok, Gresik)
}

\author{
Galih Dwi Suryanto', Dzakiyah Widyaningrum ${ }^{2}$, Moh. Jufriyanto ${ }^{3}$ \\ Program Studi Teknik Industri, Fakultas Teknik, Universitas Muhammadiyah Gresik \\ Jl. Sumatera 101 GKB, Gresik 61121, Indonesia \\ E-mail : galihdwisuryanto@gmail.com
}

\begin{abstract}
ABSTRAK
Proses produksi merupakan inti kegiatan dari suatu perusahaan. Untuk mengadakan kegiatan produksi, maka harus tersedianya bahan baku. UMKM Putroe Sarjana Gresik merupakan salah satu home industry yang mengalami permasalahan terkait perencanaan kebutuhan bahan baku yang dilakukan hanya didasarkan pada jumlah pesanan dengan kapasitas produksi, pemilik usaha berasumsi bahwa biaya persediaan akan lebih efisien dengan ultisitas mesin yang tinggi. Namun dampak yang terjadi dari kebijakan tersebut adalah UMKM putroe sarjana mengalami permasalahan tidak tersedianya bahan baku untuk memenuhi permintaan konsumen, dan mengakibatkan terjadinya keterlambatan pengiriman produk. Metode Material Requirement Planning (MRP) merupakan perencanaan bahan baku yang digunakan untuk menghitung kebutuhan bahan baku yang bersifat dependent (berdasar permintaan) terhadap penyelesaian suatu produk akhir. Maka penelitian ini bertujuan untuk, (1) menentukan permintaan produk songkok menggunakan metode Forecasting (Peramalan). (2) menentukan kuantitas dan jadwal pembelian bahan baku songkok serta jumlah persediaan minimum untuk melakukan pemesanan kembali. (3) menentukan kebutuhan persediaan bahan baku produksi songkok dengan menggunakan metode Material Requirement Planning. Hasil penelitian yang telah dilakukan menunjukkan bahwa, perencanaan persediaan dengan jumlah pemesanan dan biaya penyimpanan persediaan paling minimum adalah dengan menggunakan teknik lot sizing Lot For Lot (L-F-L) yang dipakai untuk menentukan jumlah kebutuhan bahan baku produk songkok pada periode bulan januari - desember 2021 membutuhkan Kain bludru 670 Yard, Bos-bosan Songkok 5242 Pcs dalam setahun, dan Mika 188,7 dalam setahun. Penghematan yang didapat antara perhitungan perusahaan dengan metode Lot For Lot sebesar Rp. 8.171.824.
\end{abstract}

Kata kunci : Perencanaan Kebutuhan Bahan Baku, Metode Material Requirement Planning (MRP), Lot For Lot (L-F-L), Economic Order Quantity (EOQ).

\section{PENDAHULUAN}

Perkembangan dan pertumbuhan industri di Indonesia saat ini sangat pesat, seiring dengan pesatnya ilmu pengetahuan dan teknologi yang semakin canggih, sehingga persaingan antar perusahaan semakin ketat (Palupi, dkk., 2018). Setiap perusahaan memiliki tujuan yang sama yaitu memperoleh laba atau keuntungan. Untuk mencapai tujuan tersebut perusahaan harus mampu dalam menangani faktor- faktor yang mempengaruhi pendapatan. Salah satu faktor yang mempengaruhi yaitu mengenai masalah kelancaran proses produksi (Rahmawati \& Sholichah, 2018).

Dalam kegiatan proses produksi perusahaan dituntut untuk menghasilkan suatu produk yang berkualitas yang sesuai dengan keinginan dari para konsumen (Wahyuni \& Syaichu, 2015). Bahan baku merupakan salah satu faktor penting bagi kelancaran proses produksi di perusahaan yang harus dimanfaatkan secara efektif dan efisien dalam usaha untuk menciptakan keuntungan bagi perusahaan, selain modal dan tenaga kerja (Nasution \& Prasetyawan, 2008). Pengendalian persediaan 
perlu diperhatikan karena berkaitan dengan biaya - biaya yang harus ditanggung oleh perusahaan sebagai akibat adanya persediaan. Apabila terjadi kekurangan dalam persediaan bahan baku dapat berakibat terganggunya kelancaran proses produksi.

Putroe Sarjana merupakan Home Industry atau UMKM yang bergerak dalam bidang industri pembuatan songkok atau peci yang beralamatkan di jalan H. Samanhudi Gg. VI/28 Kelurahan Pekelingan, Kecamatan Gresik, Kabupaten Gresik. UMKM Putroe Sarjana ini didirikan sejak tahun 2015, karena melihat adanya peluang berkembangnya bisnis songkok di kota Gresik. Proses produksi pembuatan songkok UMKM Putroe Sarjana dalam satu minggu mampu memproduksi songkoknya sekitar 11 kodi dengan 3 jenis songkok yaitu songkok polos, songkok lukis dan songkok bordir. Bahan baku yang digunakan yaitu kain beludru, bos-bosan penutup, bos-bosan badan, mika, dan benang.

Dalam menjalankan proses produksinya UMKM Putroe Sarjana belum menerapkan metode penentuan kebutuhan bahan baku yang optimal, hanya didasarkan pada jumlah pesanan dengan kapasitas produksi,karena berdasarkan pada penggunaan jumlah pesanan tersebut pemilik usaha berasumsi bahwa biaya persediaan akan lebih efisien dengan ultisitas mesin yang tinggi.

Namun dampak yang terjadi dari kebijakan tersebut adalah UMKM putroe sarjana akan mengalami permasalahan, diantaranya tidak tersedianya bahan baku untuk memenuhi permintaan konsumen. Tidak cukupnya bahan baku yang tersedia juga berpengaruh terhadap hasil produksi songkok dan mengakibatkan terjadinya keterlambatan pengiriman songkok. Sehingga perlu adanya pengendalian persediaan bahan baku yang dapat meningkatkan potensi kelancaran proses produksi, untuk mengetahui kebutuhan bahan baku yang optimal dan meminimalkan biaya biaya yang dapat merugikan perusahaan. Adapun data pada tahun 2020 penggunaan bahan baku aktual dan realisasi pembelian bahan baku songkok yang dapat dilihat pada tabel 1. :

Tabel 1. Penggunaan Bahan Baku Produksi dan Pembelian Bahan Baku Songkok Putroe Sarjana Tahun 2020

\begin{tabular}{|c|c|c|c|c|c|c|c|c|c|c|c|c|c|c|c|c|}
\hline \multirow[b]{2}{*}{$\begin{array}{l}\text { Periode } \\
2020\end{array}$} & \multirow[b]{2}{*}{$\mid \begin{array}{c}\text { Permintaan } \\
\text { (Pcs) }\end{array}$} & \multicolumn{5}{|c|}{ Penggunaan Bahan Baku Aktual } & \multicolumn{5}{|c|}{ Realisasi Pembelian Bahan Baku } & \multicolumn{5}{|c|}{ Stock } \\
\hline & & $\begin{array}{c}\text { Kain } \\
\text { Beludru } \\
\text { (Yard) }\end{array}$ & $\begin{array}{c}\text { Bos-bosan } \\
\text { Penutup } \\
\text { (Pcs) }\end{array}$ & $\begin{array}{c}\text { Bos-bosan } \\
\text { Badan } \\
\text { (Pcs) }\end{array}$ & $\begin{array}{c}\text { Mika } \\
\text { (m) }\end{array}$ & $\begin{array}{c}\text { Benang } \\
\text { (Roll) }\end{array}$ & $\begin{array}{c}\text { Kain } \\
\text { Beludru } \\
\text { (Yard) }\end{array}$ & $\begin{array}{c}\text { Bos-bosan } \\
\text { Penutup } \\
\text { (Pcs) }\end{array}$ & $\begin{array}{c}\text { Bos-bosan } \\
\text { Badan } \\
\text { (Pcs) }\end{array}$ & $\begin{array}{r}\text { Mika } \\
\text { (m) }\end{array}$ & $\begin{array}{c}\text { Benang } \\
\text { (Roll) }\end{array}$ & $\begin{array}{c}\text { Kain } \\
\text { Beludru } \\
\text { (Yard) }\end{array}$ & $\begin{array}{c}\text { Bos-bosan } \\
\text { Penutup } \\
\text { (Pcs) }\end{array}$ & $\begin{array}{c}\text { Bos-bosan } \\
\text { Badan } \\
\text { (Pcs) }\end{array}$ & $\begin{array}{c}\text { Mika } \\
\text { (m) }\end{array}$ & $\begin{array}{c}\text { Benang } \\
\text { (Roll) }\end{array}$ \\
\hline Januari & 200 & 20 & 200 & 200 & 8 & 2 & 33 & 210 & 210 & 9 & 3 & 13 & 10 & 10 & 1 & 1 \\
\hline Februari & 300 & 30 & 300 & 300 & 12 & 2 & 33 & 310 & 310 & 13,5 & 3 & 16 & 20 & 20 & 3 & 2 \\
\hline Maret & 200 & 20 & 200 & 200 & 8 & 2 & 33 & 210 & 210 & 9 & 3 & 29 & 30 & 30 & 4 & 3 \\
\hline April & 400 & 40 & 400 & 400 & 16 & 2 & 33 & 410 & 410 & 18 & 3 & 22 & 40 & 40 & 6 & 4 \\
\hline Mei & 400 & 40 & 400 & 400 & 16 & 2 & 33 & 410 & 410 & 18 & 3 & 15 & 50 & 50 & 8 & 5 \\
\hline Juni & 800 & 80 & 800 & 800 & 32 & 3 & 33 & 810 & 810 & 36 & 4 & -32 & 60 & 60 & 12 & 6 \\
\hline Juli & 200 & 20 & 200 & 200 & 8 & 2 & 33 & 210 & 210 & 9 & 3 & -19 & 70 & 70 & 13 & 7 \\
\hline Agustus & 300 & 30 & 300 & 300 & 12 & 2 & 33 & 310 & 310 & 13,5 & 3 & -16 & 80 & 80 & 14 & 8 \\
\hline September & 900 & 90 & 900 & 900 & 36 & 3 & 33 & 910 & 910 & 40,5 & 4 & -73 & 90 & 90 & 19 & 9 \\
\hline Oktober & 900 & 90 & 900 & 900 & 36 & 3 & 33 & 910 & 910 & 40,5 & 4 & -130 & 100 & 100 & 23 & 10 \\
\hline November & 400 & 40 & 400 & 400 & 16 & 2 & 33 & 410 & 410 & 18 & 3 & -137 & 110 & 110 & 25 & 11 \\
\hline Desember & 300 & 30 & 300 & 300 & 12 & 2 & 33 & 310 & 310 & 13,5 & 3 & -134 & 120 & 120 & 27 & 12 \\
\hline Total & 5300 & 530 & 5300 & 5300 & 212 & 27 & 396 & 5420 & 5420 & 239 & 39 & -446 & 780 & 780 & 151 & 78 \\
\hline
\end{tabular}

Sumber : UMKM Putroe Sarjana, 2020

Dilihat dari tabel diatas UMKM Putroe Sarjana mengalami kekurangan bahan baku kain beludru pada bulan Juni sampai dengan Desember 2020 apabila melakukan jumlah pemesanan yang terlalu rendah dan mengalami over stock/penumpukan bahan baku di gudang dengan melakukan pemesanan yang terlalu tinggi dari jumlah yang dibutuhkan. Oleh karena itu dalam penelitian ini akan dilakukan perencanaan kebutuhan terhadap bahan baku 
produk songkok agar UMKM Putroe Sarjana tidak mengalami kekurangan dan over stock. Salah satu metode yang akan digunakan sebagai alternatif solusi untuk permasalahan tersebut adalah metode Material Requirement Planning (MRP). Sistem MRP dikembangkan untuk membantu perusahaan dalam mengatasi kebutuhan akan item - item tertentu secara lebih baik dan efisien (Nasution \& Prasetyawan, 2008). Selain itu MRP juga didasarkan pada permintaan untuk sebuah jenis barang yang berkaitan dengan permintaan jenis barang yang lain. Diharapkan dengan menggunakan metode MRP perusahaan dapat mengatur jadwal secara teliti terhadap persediaan bahan baku dan dapat direvisi bila terdapat perubahan pada perencanaan bahan baku.

\section{METODE PENELITIAN}

Penelitian ini dilakukan pada UMKM Putroe Sarjana dengan melakukan pengamatan berupa observasi lapangan yaitu mengunjungi UMKM Putroe Sarjana yang beralamatkan di jalan H. Samanhudi Gg. VI/28 Kelurahan Pekelingan, Kecamatan Gresik, Kabupaten Gresik dan melakukan wawancara kepada pemilik UMKM. Selanjutnya dilakukan Studi literatur dengan landasan teori yang dapat diperoleh dari buku - buku, jurnal, artikel, karya tulis ilmiah dan lain sebagainya yang berhubungan dengan obyek dan proses penelitian. Seperti jurnal tentang pengendalian persediaan, dan buku-buku mengenai Forecasting (peramalan) dan Material Requirement Planning (MRP).

Dalam identifikasi permasalahan ini terletak pada proses pengendalian persediaan bahan baku untuk pembuatan produk songkok. Identifikasi masalah ini akan mencakup yang ada pada proses pengendalian persediaan bahan baku pada UMKM Putroe Sarjana.sehingga didapat perumusan masalah yang akan dibahas dan kemudian dikembangkan dengan cara mencari informasi dan data yang berhubungan dengan permasalahan tersebut. Dengan tujuan dapat menetapkan batasan batasan beserta asumsi yang diperlukan untuk memudahkan dan mengurangi komplesitas atau perluasan yang akan diselesaikan.

Selanjutnya akan dilakukan pengumpulan data yang akan digunakan untuk menganalisis dengan metode Material Requirement Planning (MRP) untuk mengetahui lebih detail persoalan yang ada. Adapun pengumpulan data yang dimaksudkan adalah sebagai berikut :

1) Data jumlah Permintaan Produksi Pada Periode Januari s/d Desember 2020.

2) Data Stock Akhir Bahan Baku Periode Desember 2020.

3) Data Bill Of Material (BOM) Produk Songkok.

4) Proses Operasi

5) Data Harga Bahan Baku Periode Januari s/d Desember 2020.

6) Data Biaya Penyimpanan dan Biaya Pemesanan Periode Januari s/d Desember 2020.

Selanjutnya dilakukan pengolahan data yang bertujuan untuk mengolah data-data yang sudah didapat pada penelitian dengan metode yang digunakan dalam pengolahan data pada penilitan ini adalah metode Forecasting (peramalan) dan Material Requirement Planning (MRP) : berikut adalah penjelasan mengenai pengolahan data dengan metode tersebut :

1. Forecasting (peramalan)

Tahapan dalam pengolahan data menggunkan Forecasting (peramalan) adalah sebagai berikut :

a) Menentukan pola data

b) Melakukan perhitungan data peramalan pada masa yang akan datang dengan pemilihan beberapa metode dengan memilih error terkecil dengan melihat dari MAPE, MAD,MSE. Dari perhitungan ini maka didapatkan hasil peramalan yang memiliki error terkecil

\section{Material Requirement Planning (MRP)}

Tahapan dalam pengolahan data menggunakan Material Requirement Planning (MRP) adalah sebagai berikut :

a) Menentukan Jadwal Induk Produksi (JIP)/ Master Production Schedule (MPS) produk songkok. Untuk menentukan Jadwal Induk Produksi (JIP) didapatkan dari hasil peramalan permintaan produk songkok. 
b) Melakukan Logic Material Requirement Planning dengan melakukan Netting, Lotting, Offsetting, dan Explosion. Sebagai berikut :

a. Netting yaitu menghitung kebutuhan bersih

b. Lotting yaitu melakukan perhitungan menggunakan teknik Lot Sizing : Lot For Lot (L-4-L) dan Economic Order Quantity (EOQ).

c. Offsetting yaitu untuk mmenentukan saat yang tepat untuk melakukan rencana pemesanan dalam rangka memenuhi kebutuhan bersih.

d. Explosion yaitu proses perhitungan item/ barang yang ada pada struktur yang lebih bawah. Perhitungan yang dilakukan berdasarkan rencana pemesanan untuk produk yang ada di atasnya /proses penguraian kebutuhan dalam bagian produk yang paling kecil.untuk Mendapatkan hasil yang optimal dan lebih ifisien dengan membandingkan antara metode yang digunakan perusahaan sekarang dengan menggunakan metode Material Requirement Planning (MRP) dalam perencanaan persediaan kebutuhan bahan baku songkok. Sehingga nanti metode MRP dengan teknik Lot Sizing yang digunakan yaitu Lot For Lot dan Economic Order Quantity yang nantinya akan dibandingkan dengan mengggunakan metode perusahaan sehingga akan dipilih metode MRP dengan teknik Lot Sizing yang paling rendah.

\section{HASIL DAN PEMBAHASAN}

\subsection{Pengumpulan Data}

Data - data yang digunakan oleh peneliti bersumber dari UMKM Putroe Sarjana Songkok. Produk songkok yang diteliti adalah untuk semua ukuran dengan proses produksi sampai model polos yang terbuat dari bahan dasar kain beludru, bos-bosan penutup, bosbosan badan, mika dan benang. Berikut merupakan BOM untuk produk songkok yang dapat dilihat pada gambar 1 .

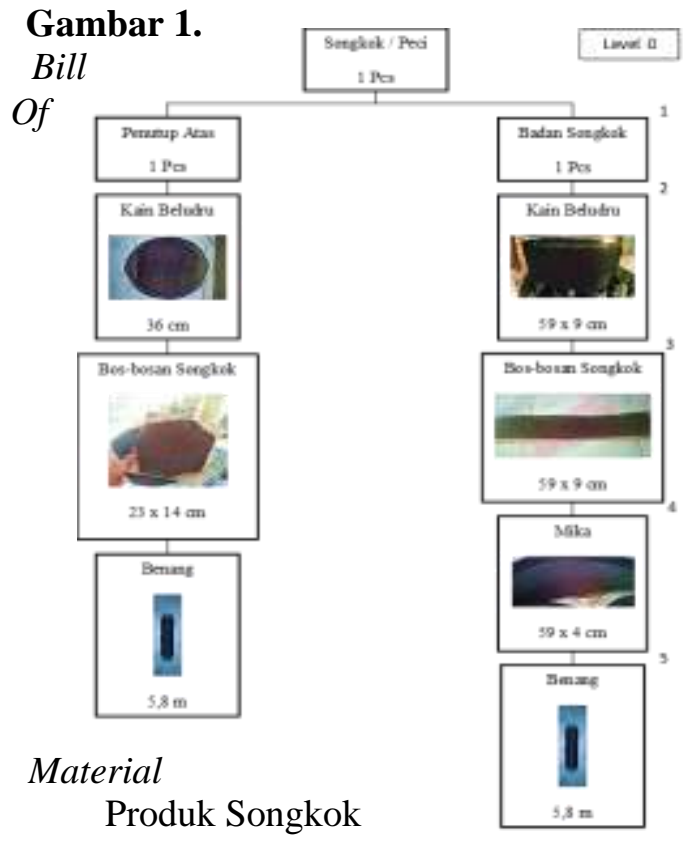

Sumber : pengolahan data

Selanjutnya akan dilakukan pengumpulan data permintaan produksi songkok, perhitungan biaya simpan, biaya pesan setiap unit dan data persediaan akhir. Untuk permintaan produksi dapat dilihat pada tabel 2 .

Tabel 2. Data produksi songkok periode per bulan Januari - Desember 2020

\begin{tabular}{|l|c|c|}
\hline $\begin{array}{c}\text { Periode } \\
2020\end{array}$ & $\begin{array}{c}\text { Produksi } \\
\text { (Kodi) }\end{array}$ & $\begin{array}{c}\text { Produksi } \\
\text { (Pcs) }\end{array}$ \\
\hline Januari & 10 & 200 \\
\hline Februari & 15 & 300 \\
\hline Maret & 10 & 200 \\
\hline April & 20 & 400 \\
\hline Mei & 20 & 400 \\
\hline Juni & 40 & 800 \\
\hline Juli & 10 & 200 \\
\hline Agustus & 15 & 300 \\
\hline September & 45 & 900 \\
\hline Oktober & 45 & 900 \\
\hline November & 20 & 400 \\
\hline Desember & 15 & 300 \\
\hline \multicolumn{2}{|l|}{ Sumber : UMKM Putroe Sarjana,2020 }
\end{tabular}


Untuk rincian data biaya dapat dilihat pada perhitungan dibawah ini :

A. Biaya simpan seluruh bahan baku:

- Perhitungan Listrik :

- 1 bulan = 30 hari

- Lampu yang digunakan $=15$ Watt

- Jumlah lampu = 2

- Pemakaian = $12 \mathrm{Jam}$

- Harga Listrik PerKwh = Rp. 1.325/Kwh

Jadi penggunaan perhari adalah $2 \times 15 \times 12$

$=360$ Watt. Maka 360 Watt : $1000=$ $0,36 /$ Kwh. Maka 0,36 x $1.352=487 /$ hari x 30 hari $=$ Rp. 14.610

B. Biaya Pesan bahan baku:

a. Kain Beludru

$$
\begin{array}{ll}
\text { 1. } \text { Biaya Transport } & =\text { Rp. } 10.000 \\
\text { 2. Biaya Telepon } & =\text { Rp. } 1.500 \\
\hline & =\text { Rp. } 11.500
\end{array}
$$

b. Bos-bosan Penutup \& Badan

$$
\begin{aligned}
& \text { 1. Biaya Transport }=\text { Rp. } 10.000 \\
& \text { 2. } \text { Biaya Telepon =Rp. } 1.500 \\
& =\text { Rp. } 11.500
\end{aligned}
$$

c. Mika

$$
\begin{array}{ll}
\text { 1. } \begin{array}{l}
\text { Biaya Transport } \\
\text { 2. } \text { Biaya Telepon }
\end{array} & =\text { Rp. } 10.000 \\
\hline & =\text { Rp. } 11.500
\end{array}
$$

d. Benang

e. Biaya Transport= Rp. 10.000

\begin{tabular}{|l|l|c|c|}
\hline \multicolumn{1}{|c|}{ Nama Bahan } & Harga Bahan & $\begin{array}{c}\text { Biaya simpan } \\
\text { seluruh bahan } \\
\text { baku/bulan }\end{array}$ & $\begin{array}{c}\text { biaya pesan } \\
\text { seluruh bahan } \\
\text { baku/Pesan }\end{array}$ \\
\hline Kain Beludru & Rp. $36.900 /$ yard & & \\
\cline { 1 - 2 } Bos-bosan Penutup & Rp. $1.250 / \mathrm{pcs}$ & & \\
\cline { 1 - 2 } Bos-bosan Badan & Rp. $1.500 / \mathrm{pcs}$ & \multirow{2}{*}{ Rp. $14.610 /$ bulan } & Rp. $46.000 /$ bulan \\
\cline { 1 - 2 } Mika & Rp. $8.000 / \mathrm{m}$ & & \\
\hline Benang & Rp. $14.500 /$ roll & & \\
\hline
\end{tabular}

f. $\quad$ Biaya Telepon $=$ Rp. 1.500

$$
=\text { Rp. } 11.500
$$

Tabel 3. Data Biaya Bahan Baku Produk Songkok

Sumber : UMKM Putroe Sarjana,2020

Data penyimpanan persediaan bahan baku songkok pada bulan Desember 2020 dapat dilihat pada tabel 4 .
Tabel 4. Persediaan akhir bahan baku songkok tahun 2020

Sumber : UMKM Putroe Sarjana,2020

\section{Pengolahan Data}

Selanjutnya peneliti menganalisis hasil penelitian yang didasarkan dari data yang diperoleh. Pada tahapan ini dilakukan analisis mengenai peramalan, perencanaan persediaan dan Material Requirement Planning.

Dalam peramalan, langkah awal yang digunakan adalah menentukan pola data memiliki kecenderungan atau tidak.dari hasil gambar 2 dibawah diketahui bahwa pola data membentuk kecenderungan yang tidak stabil serta musiman dimana, unsur musimannya bersifat multiplikatif. Sehingga dapat menggunakan peramalan dengan Weighted Moving Average dan Metode Winter's.

Gambar 2. Pola Data Produksi Songkok Plot Data Pemintaan Produksi Songkok Tahun 2020

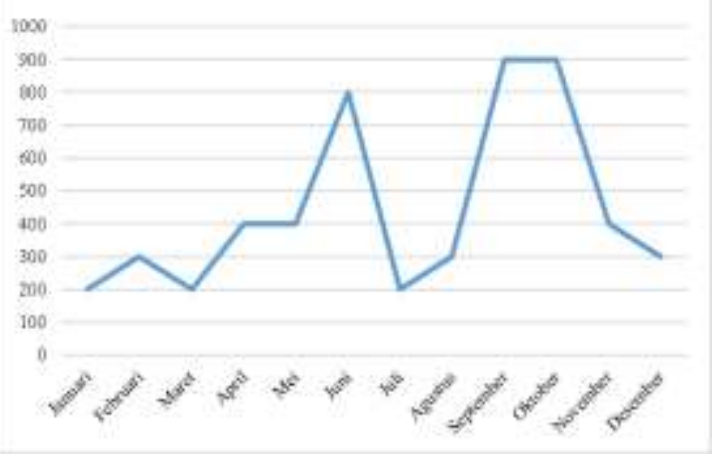

Sumber : pengolahan data

Berdasarkan pola data yang membentuk kecenderunga tidak stabil serta musiman dimana, unsur musimannya bersifat multiplikatif maka dalam penelitian ini metode Weighted Moving Average dengan $\mathrm{N}=3, \mathrm{~W}=$ 0,$5 ; 0,3 ; 0,2$ dan Metode Holt-Winter Multiplikative dengan konstanta pemulusan dengan nilai $\alpha=0,5 ; \beta=0,5 ; \gamma=0,5$. Dari kedua metode yang dipilih maka dilakukan pemilihan metode terbaik berdasarkan MAD, MSE, dan MAPE yang terkecil.

Tabel 5. Perbandingan Hasil Peramalan

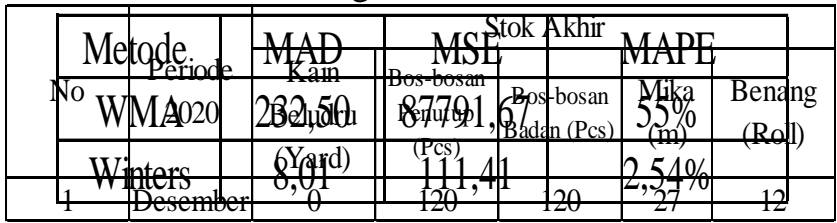


Sumber : pengolahan data

Berdasarkan tabel 5 di atas dapat diketahui bahwa dari 2 metode yang digunakan diperoleh MAD terkecil 8,01 dengan metode Holt-Winter Multiplikative. Langkah selanjutnya melakukan peramalan berdasarkan metode Holt-Winter Multiplikative yang mempunyai MAD terkecil untuk menentukan kebutuhan persediaan di masa mendatang.

Perencanaan persediaan dilakukan berdasarkan metode peramalan terpilih dengan menggunakan Holt - Winter Multiplikative yang dapat diketahui permintaan produksi songkok di UMKM Putroe Sarjana untuk satu tahun ke depan sesuai dengan tabel 6 .

Tabel 6. Ukuran Lot kebutuhan Bahan Baku Tahun 2021

\begin{tabular}{|c|c|c|c|c|c|c|c|}
\hline \multirow[t]{2}{*}{ No. } & \multirow[t]{2}{*}{ Periode 2021} & \multirow[t]{2}{*}{$\begin{array}{c}\text { Forecast } \\
\text { (Pcs) }\end{array}$} & $\begin{array}{c}\text { Kain } \\
\text { Beludru } \\
\text { (Yard) }\end{array}$ & $\begin{array}{c}\text { Bos-bosan } \\
\text { Penutup } \\
\text { (Pcs) }\end{array}$ & $\begin{array}{c}\text { Bos-bosan } \\
\text { Badan } \\
\text { (Pcs) }\end{array}$ & Mika (m) & $\begin{array}{c}\text { Benang } \\
\text { (Roll) }\end{array}$ \\
\hline & & & \multicolumn{5}{|c|}{ Pemakaian } \\
\hline 0 & $\begin{array}{l}\text { tahun } \\
\text { sebelumnya }\end{array}$ & 0 & 134 & - & - & - & - \\
\hline 1 & Januari & 212 & 155,2 & 212 & 212 & 8,5 & 2 \\
\hline 2 & Februari & 323 & 32,3 & 323 & 323 & 12,9 & 2 \\
\hline 3 & Maret & 213 & 21,3 & 213 & 213 & 8,5 & 2 \\
\hline 4 & April & 417 & 41,7 & 417 & 417 & 16,7 & 3 \\
\hline 5 & Mei & 409 & 40,9 & 409 & 409 & 16,4 & 3 \\
\hline 6 & Juni & 804 & 80,4 & 804 & 804 & 32,2 & 4 \\
\hline 7 & Juli & 199 & 19,9 & 199 & 199 & 8,0 & 2 \\
\hline 8 & Agustus & 298 & 29,8 & 298 & 298 & 11,9 & 2 \\
\hline 9 & September & 893 & 89,3 & 893 & 893 & 35,7 & 4 \\
\hline 10 & Oktober & 895 & 89,5 & 895 & 895 & 35,8 & 4 \\
\hline 11 & November & 399 & 39,9 & 399 & 399 & 16,0 & 2 \\
\hline 12 & Desember & 300 & 30,0 & 300 & 300 & 12,0 & 2 \\
\hline & Total & 5362 & 670 & 5362 & 5362 & 214,5 & 32 \\
\hline
\end{tabular}

MRP memerlukan jadwal Induk Produksi (Master Production Schedule) dan status persediaan. Dalam penelitian ini jadwal induk produksi diasumsikan dari data peramalan kebutuhan produk songkok dan status persediaan menyimpan informasi yang lengkap tentang keadaan persediaan.

Dari tabel 7, dapat dilihat dari perhitungan menggunakan metode perusahaan memiliki biaya persediaan bahan baku kain beludru lebih rendah dibandingkan perhitungan biaya dengan menggunakan metode Lot For Lot dan Economic Order Quantity. Namun dampak yang terjadi dari hasil perhitungan perusahaan tersebut ialah menyebabkan kekurangan bahan baku dalam memenuhi kebutuhan produksi, yang mengakibatkan perusahaan mengalami ketidaklancaran produksi. Sehingga dalam penelitian ini metode yang dipilih adalah menggunakan metode Lot For Lot dengan nilai Rp. 43.395.932. karena karena memiliki total biaya terkecil dari pada teknik Economic Order Quantity (EOQ). Dapat dilihat pada tabel

\begin{tabular}{|c|c|c|c|c|c|c|c|}
\hline \multirow[b]{2}{*}{ Bahan Baku } & \multirow[b]{2}{*}{ Satuan } & \multicolumn{2}{|c|}{ Lot For Lot } & \multicolumn{2}{|c|}{ Economic Order Quantity } & \multicolumn{2}{|c|}{ Total Biaya Perusahaan } \\
\hline & & $\begin{array}{c}\text { Planned } \\
\text { Order } \\
\text { Release }\end{array}$ & Total Biaya & $\begin{array}{c}\text { Planned } \\
\text { Order } \\
\text { Release }\end{array}$ & Total Biaya & $\begin{array}{c}\text { Planned } \\
\text { Order } \\
\text { Release }\end{array}$ & Total Biaya \\
\hline Kain Beludru & Yard & 670 & Rp25.282.380 & 672 & Rp25.348.800 & 396 & Rp15.232.580 \\
\hline Bos-bosan Penutup & Pcs & 5242 & Rp7.088.318 & 5260 & Rp7.210.132 & 5420 & Rp7.490.632 \\
\hline Bos-bosan Badan & Pcs & 5242 & Rp8.398.818 & 5260 & Rp8.525.132 & 5420 & Rp8.845.632 \\
\hline Mika & M & 188,7 & Rp1.980.690 & 189 & Rp2.158.632 & 239 & Rp2.627.632 \\
\hline Benang & Roll & 23 & Rp645.726 & 24 & Rp597.542 & 39 & Rp1.027.632 \\
\hline \multicolumn{2}{|c|}{ Total Biaya } & \multicolumn{2}{|c|}{ Rp43.395.932 } & \multicolumn{2}{|c|}{ Rp43.840.238 } & \multicolumn{2}{|c|}{ Rp35.224.108 } \\
\hline
\end{tabular}

Tabel 7.Perbandingan Biaya Total Hasil MRP

Sumber : pengolahan data 


\begin{tabular}{|c|c|c|c|c|c|c|c|c|c|c|c|c|c|c|c|c|c|c|c|c|c|c|c|c|c|}
\hline $\begin{array}{l}\text { Material } \\
\text { Lead Time }\end{array}$ & $\begin{array}{l}\text { :Songk } \\
: 1 \text { ming }\end{array}$ & & & & & & & & $\begin{array}{l}\text { Lot Siz } \\
\text { Safety }\end{array}$ & $\begin{array}{l}\text { izing } \\
\text { Stock }\end{array}$ & & & $\begin{array}{l}: \text { L } 4 \mathrm{I} \\
: 5 \mathrm{ko}\end{array}$ & & & & & & & & & & & & \\
\hline \multirow{2}{*}{ Periode } & \multirow{2}{*}{0} & \multicolumn{4}{|c|}{ Jan-21 } & \multicolumn{4}{|c|}{ Feb-21 } & \multicolumn{4}{|c|}{ Mar-21 } & \multicolumn{4}{|c|}{ Apr-21 } & \multicolumn{4}{|c|}{ Mei-21 } & \multicolumn{4}{|c|}{ Jun-21 } \\
\hline & & 1 & 2 & 3 & 4 & 1 & 2 & 3 & 4 & 1 & 2 & 3 & 4 & 1 & 2 & 3 & 4 & 1 & 2 & 3 & 4 & 1 & 2 & 3 & 4 \\
\hline Gross Requirement & & 2,8 & 2,6 & 2,6 & 2,6 & 4,15 & 4 & 4 & 4 & 2,7 & 2,65 & 2,65 & 2,65 & 5,25 & 5,2 & 5,2 & 5,2 & 5,2 & 5,1 & 5,1 & 5,1 & 10,2 & 10 & 10 & 10 \\
\hline Schedule Receipt & & 3 & 2,4 & 2,6 & 2,6 & 4,15 & 4 & 4 & 4 & 2,7 & 2,65 & 2,65 & 2,65 & 5,25 & 5,2 & 5,2 & 5,2 & 5,2 & 5,1 & 5,1 & 5,1 & 10,2 & 10 & 10 & 10 \\
\hline \begin{tabular}{|l|} 
Projected On Hand \\
\end{tabular} & 5 & 5,2 & 5 & 5 & 5 & 5 & 5 & 5 & 5 & 5 & 5 & 5 & 5 & 5 & 5 & 5 & 5 & 5 & 5 & 5 & 5 & 5 & 5 & 5 & 5 \\
\hline Net Requirement & & & 2,4 & 2,6 & 2,6 & 4,15 & 4 & 4 & 4 & 2,7 & 2,65 & 2,65 & 2,65 & 5,25 & 5,2 & 5,2 & 5,2 & 5,2 & 5,1 & 5,1 & 5,1 & 10,2 & 10 & 10 & 10 \\
\hline \multicolumn{2}{|c|}{ Planned Order Release } & 2,4 & 2,6 & 2,6 & 4,15 & 4 & 4 & 4 & 2,7 & 2,65 & 2,65 & 2,65 & 5,25 & 5,2 & 5,2 & 5,2 & 5,2 & 5,1 & 5,1 & 5,1 & 10,2 & 10 & 10 & 10 & 2,6 \\
\hline
\end{tabular}

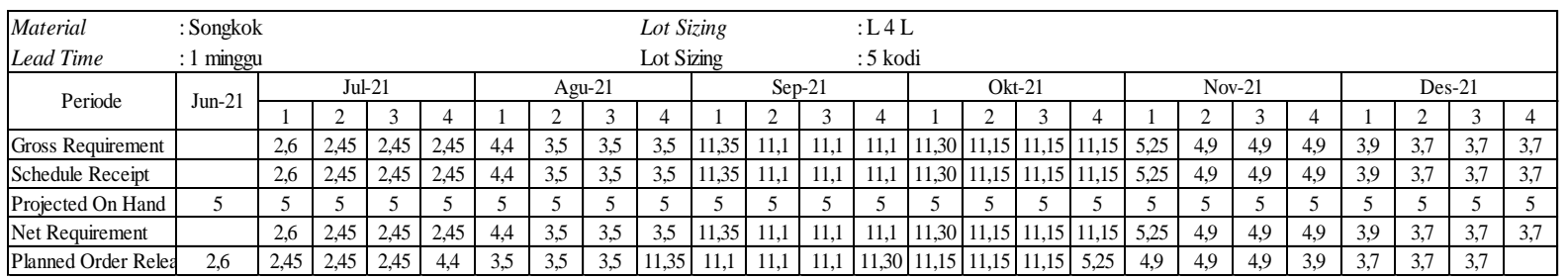

Tabel 8. Perhitungan MRP pada Produk Songkok Dengan Metode L-F-L

Sumber : pengolahan data

Tabel 8. Perhitungan MRP pada Produk Songkok Dengan Metode L-F-L Sumber : pengolahan data

\section{SIMPULAN}

Kesimpulan dari penelitian yang dilakukan di UMKM Putroe Sarjana berdasarkan hasil dari pengolahan data dan analisa hasil dengan menggunakan metode Material Requirement Planning (MRP) didapatkan kesimpulan sebagai berikut:

Permalan (Forecasting) yang dipakai dalam menentukan peramalan produk songkok pada periode Januari - Desember 2021 adalah menggunakan peramalan dengan metode Winter's dengan model Multiplicative karena mempunyai tingkat error atau tingkat kesalahan yang paling kecil dengan nilai MAD, MSE, dan MAPE paling kecil yaitu 8,$01 ; 111,41 ; 2,54 \%$. Sehingga yang dipakai adalah metode Winter's dengan model Multiplicative dibanding dengan metode Weighted Moving Average.

Untuk mengetahui jumlah pemesanan kain beludru, bos-bosan songkok, dan mika menggunakan metode (L-4-L) ialah dilakukan pemesanan dengan frekuensi 48 kali pesan dalam setahun dan pemesanan dilakukan sesuai dengan kebutuhan permintaan produksi.

Sedangkan berdasarkan hasil pengolahan data dan analisis hasil untuk menentukan rencana pemesanan dengan menggunakan metode MRP (Material Requirement Planning) dengan perhitungan Lot Sizing menggunakan teknik Lot For Lot dan Economic Order Quantity (EOQ), pada persediaan bahan baku songkok dapat ditarik kesimpulan bahwa rencana pemesanan dengan jumlah biaya persediaan paling minimum adalah menggunakan teknik Lot Sizing Lot For Lot karena memiliki total biaya persediaan lebih rendah dibandingkan persediaan yang sudah dilakukan oleh perusahaan dengan catatan dapat memenuhi kebutuhan produksi dan Teknik Lot For Lot ini mempertimbangkan kuantitas pembelian yang menyeimbangkan biaya pemesanan, meminimumkan biaya simpan, sehingga dengan teknik ini ongkos simpan menjadi nol. Untuk menentukan jumlah kebutuhan bahan baku untuk membuat produk songkok pada periode bulan januari - desember 2021 membutuhkan Kain bludru 670 Yard, Bosbosan Songkok 5242 Pcs dalam setahun, dan Mika 188,7 dalam setahun. Penghematan yang didapat antara perhitungan perusahaan dengan metode Lot For Lot menghemat sebesar Rp. 8.171.824

\section{PUSTAKA ACUAN}

Nasution, A. H., \& Prasetyawan, Y. (2008). Perencanaan \& Pengendalian Produksi. Yogyakarta: Graha Ilmu. 
Palupi, P. M., Korawijayanti, L., \& Handoyono, R. (2018). Penerapan Metode Economic Order Quantity (EOQ) Untuk Meningkatkan Efisiensi Biaya Persediaan Bahan Baku (Studi Kasus pada PT. Nusamulti Centralestari). Prosiding Seminar Nasional Unimus, 426-435.

Rahmawati, N., \& Sholichah, A. A. (2018, Juni). Pengendalian Persediaan Material Untuk Memenuhi Sistem Produksi Make To Order Menggunakan Material Requirement Planning. Journal of Research and Technology, 4, 1-12.

Wahyuni, A., \& Syaichu, A. (2015). Perencanaan Persediaan Bahan Baku Dengan Menggunakan Metode Material Requirement Planning (MRP) Produk Kacang Shanghai Pada Perusahaan Gangsar NgunutTulungagung. Jurnal Spektrum Industri, 151-156.

Hidayat, H., Jufriyanto, M., \& Rizqi, A. (2021). Perancangan RCM (Reliability Centered Maintenance) Untuk Mengurangi Downtime Mesin Pembuat Botol (Studi Kasus PT IGLAS (Persero), Gresik). MATRIK : Jurnal Manajemen Dan Teknik Industri Produksi, 21(2), 157 164. doi:10.30587/matrik.v21i2.2038

Hidayat, H. (2020). Application of the EOQ (Economic Order Quantity) Method in Determining Chemical Supplies in PT. Semen Indonesia. International Journal of Science, Engineering and Information Technology, 5(1), 226-230. 